\title{
correspondence
}

\section{Czech mathematician}

SIR,-On January 10, 1975, a petition was submitted to the Czech embassy in the Netherlands, concerning the position of the Czech mathematician and computer scientist Professor Karel Culik. The petition was worded as follows:

"The undersigned mathematicians and computer scientists are deeply concerned with the present position of Professor Karel Culik. Although his work has done much for the worldwide renown of Czech mathematics he is at the present time prevented from taking part in normal scientific activity; he has no position in his own country and at the same time cannot obtain permission to accept the offers he has from universities in foreign countries. The undersigned strongly urge the Czech authorities that Karel Culik be allowed shortly to pursue his career as a researcher and a scientist."

The petition was initiated by the European Association for Theoretical Computer Science, and signed by 238 scientists from 12 countries.

Yours faithfully,

\section{J. W. DE BAKKER}

(Vice-President, European

Association for Theoretical

Computer Science),

Amsterdam, Netherlands

\section{Consultancy}

SIR,--Two correspondents (December 13 and January 17) have recently criticised the way in which university staff misuse the facilities at their disposal by carrying out consultancy work.

There are other ways in which university staff take advantage of their position, particularly their flexible hours of work. Many for example mark GCE examination papers, or act as GCE examination supervisors, or as tutors at Open University Summer Schools. For these duties they are either paid or receive generous expenses. Yours faithfully, DERRICK BAXBY

University of Liverpool, UK

\section{Golden handshake}

SIR,-YYou make the proposal (January 10) that the golden handshake is the solution to the job stagnation problem in British universities. As a younger lecturer (holding an appointment in dental biochemistry) I feel such a measure would only make the situation worse. Senior experienced staff would be removed and this would only add to the administrative duties and frustration of younger colleagues at the most intellectually fertile period of their careers.

An alternative solution to the problem would be the introduction of opportunities for lecturers who wish to retrain for other professions in the middle of their careers, with financial assistance during this period of training comparable to their existing salaries. Those in their late thirties still have 60 to $70 \%$ of their active careers before them.

The people concerned are first-rate men and women, who have reached their present positions in a highly competitive and selective field. Prior experience in academic life could make an important contribution to a subsequent career in a different profession. For example, the experience and knowledge gained by a biochemistry lecturer would be an invaluable asset to someone subsequently studying medicine.

Mid-course retraining is already practised in industry; it could well offer the solution to the academics' problems too.

University of Glasgow, UK

\section{Josie A. BEeley}

\section{For those in peril}

SIR,-Your correspondents in this series (October 18, November 22, November 29) do not distinguish clearly between the scientific and political aspects of pollution. Peter J. Smith's statement that "asbestos products (and thousands of other equally or more dangerous substances) are here to stay" is not a law of nature, it is a political statement. It indicates that we are prepared to pay, wittingly or unwittingly, with our own, or other people's tissues for the goods and services that these substances offer.

To be able to say under what conditions they are to stay, the scientists will have to tell us about the medical effects of existing pollutants in industrial environments and in the general environment, whether the effects are dose-related, how concentrations can be monitored, and how potential pollutants can be recognised-all difficult, expensive and time consuming problems. But the medical scientist cannot judge this-to him all avoidable tissue damage is totally abhorrent. 'Public opinion' has to decide how much discomfort or loss of years an individual must pay.

How can the cost or risk for each pollutant be presented intelligibly for the public to judge its acceptability? Setting out the expected health effects, as for $\mathrm{SO}_{2}$ and smoke, is one way. But concentration-time scales would incorporate commercial and political realities. $\mathrm{LD}_{110}$ (concentration $X$ for $N$ years) is bad for business (and votes). A lower product for ill-health may be commercially acceptable in terms of lost man hours or compensation, but becomes less acceptable in the context of individual workers.

But the data must be sound. Unsound scientific or political activism could so limit industrial or daily activity that ill-health from pollutants could become replaced by poverty.

W. F. WHIMSTER

London SE3, UK

\section{The economics of recycle}

SIR,-In order to put recycle in a proper perspective (January 17), it is necessary to remember the following factors:

The future availability and price of key raw materials, as well as of oil, have been placed in doubt by the events of the past year. These events have emphasised the need to conserve our national resources. Recycle, or reuse of materials, is an important aspect of the proper management of these resources. It is, however, but one aspect and should be operating along with other measures such as improved design and reduction in waste both in manufacture and use.

Recycle is only viable for those materials which can be collected, reprocessed and made into products which can be sold at competitive prices. The problems are therefore basically technical and economic.

T. S. MCRoberts

Wolfson Recycle Unit,

Queen Mary College, London, UK

\section{Nutrition}

SiR, -I would be grateful if you would make it clear that the views expressed by Mr John Rivers in your article entitled "Between combine harvester and ribosome" (January 10) is an expression of his own views. The article should not be regarded as an official pronouncement of this institute.

\section{G. Goodwin}

\section{Nuffield Institute \\ of Comparative Medicine, \\ Zoological Society of London, UK}

